\title{
Water Balance of Two Major Soil Types of the Texas High Plains: Implications for Dryland Crop Production
}

\author{
Robert J. Lascano ${ }^{1 *}$, Gary R. Leiker ${ }^{1}$, Timothy S. Goebel' ${ }^{2}$, Steven A. Mauget ${ }^{1}$, Dennis C. Gitz III ${ }^{1}$ \\ ${ }^{1}$ Wind Erosion and Water Conservation Research Unit, USDA-ARS, Lubbock, TX, USA \\ ${ }^{2}$ Department of Plant and Soil Science, Texas Tech University, Lubbock, TX, USA \\ Email: *Robert.Lascano@usda.gov
}

How to cite this paper: Lascano, R.J., Leiker, G.R., Goebel, T.S., Mauget, S.A. and Gitz III, D.C. (2020) Water Balance of Two Major Soil Types of the Texas High Plains: Implications for Dryland Crop Production. Open Journal of Soil Science, 10, 274-297. https://doi.org/10.4236/ojss.2020.107015

Received: May 28, 2020

Accepted: July 14, 2020

Published: July 17, 2020

Copyright $\odot 2020$ by author(s) and Scientific Research Publishing Inc. This work is licensed under the Creative Commons Attribution International License (CC BY 4.0).

http://creativecommons.org/licenses/by/4.0/

\begin{abstract}
Crop production in the Texas High Plains is shifting from irrigated to dryland due to the increase of the depth to the water table from the Ogallala aquifer in regions where the saturated thickness of $9 \mathrm{~m}$, the minimum to sustain irrigation, has been reached. Our objective was to use the mechanistic model ENWATBAL to evaluate the daily and annual water balance for three scenarios of rainfall in this region, a dry $(189 \mathrm{~mm})$, an average $(449 \mathrm{~mm})$ and a wet $(669 \mathrm{~mm})$ year. These three scenarios were applied to two major soil series of this region, Pullman and Amarillo. In all simulations, we used hourly input weather data for a location near Lubbock, Texas and used measured soil hydraulic properties to simulate the water balance for each soil series and the three rainfall scenarios. Results showed that in years with average and wet rain, storage of rainfall occurred in the Pullman but not in in the Amarillo soil series. However, storage of water could be enhanced by combining furrow dikes with minimum tillage along with crop covers that provide a surface residue. The implications of our results for dryland crop production in the semiarid climate of the THP suggest that for years with average and wetter rainfall soils in the Pullman series could store water that would be available for crop use. However, this was not the case for the Amarillo soil series and these soils represent a higher risk for dryland crop production.
\end{abstract}

\section{Keywords}

Irrigation, Water Use Efficiency, Simulation, Rainfall, Ogallala Aquifer

\section{Introduction}

The history of irrigation in the Texas High Plains (THP) is well documented [1] 
[2] and the source of nearly all of the irrigation-water is from the Ogallala aquifer [3]. In this region, large-scale irrigation started in the 1920s and water from the Ogallala aquifer was initially withdrawn using windmills and then shifted to pumps with the development of internal combustion engines [4]. The Ogallala aquifer covers eight states (Wyoming, South Dakota, Nebraska, Colorado, Kansas, New Mexico, Oklahoma and Texas) of the Great Plains of USA (Figure 1) and an estimated status of the aquifer in the THP is shown in Figure 2. The status of the aquifer is based on a requirement of a saturation thickness of $9 \mathrm{~m}$ ( 30 feet) as the minimum value to sustain irrigation.

In the THP, the Ogallala aquifer is classified as a closed system, where withdrawals exceed recharge, and thus over the years the depth to the water table has increased [4] [5] [6] [7]. The major withdrawal of water is mainly due to irrigation of crops and has resulted in a depletion of groundwater to the extent that in several parts of the THP existing irrigation wells can only supply $<50 \%$ of the daily water requirement of crops [8] [9]. This decline of the groundwater here and elsewhere has prompted considerable research on irrigation scheduling, i.e., when and how much water to apply, and on the development of irrigation systems suited for this region. Examples of irrigation scheduling methods developed were canopy temperature-based indices [10] [11], temperature-time thresholds [12] [13], evapotranspiration-based methods [14], and plant-based methods [15] among others. An example of an irrigation system suited for this region is the method known as Low Energy Precision Application (LEPA), which is a sprinkler system developed for well capacities that can deliver 1.3 to $>7 \mathrm{~mm} / \mathrm{d}$ of the daily water requirements of a crop and to also make use of seasonal rain [16] [17]. However, in many regions of the THP it is the well capacity that often dictates the amount of irrigation-water that can be applied regardless of

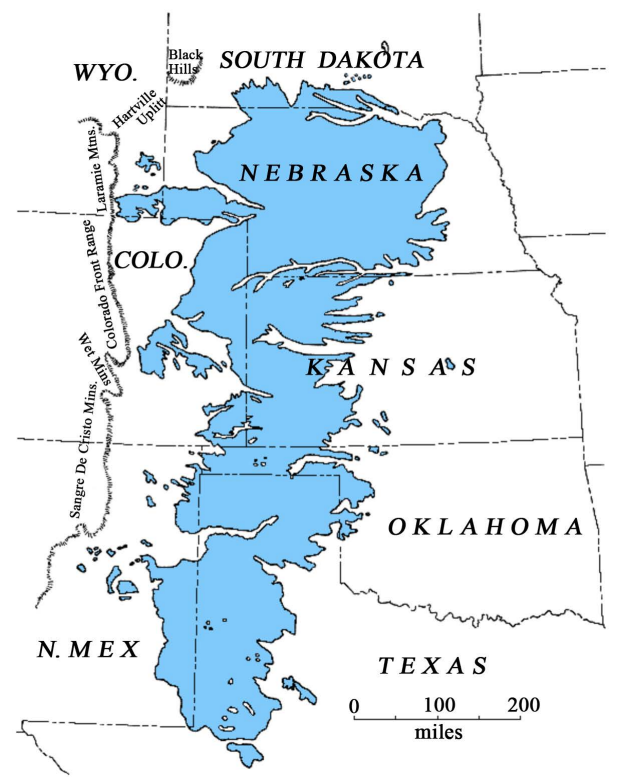

Figure 1. The Ogallala aquifer in the Great Plains of the USA (from: Kansas Geological Survey, http://www.kgs.ku.edu/publications/Bulletins/162/gifs/fig006.gif). 


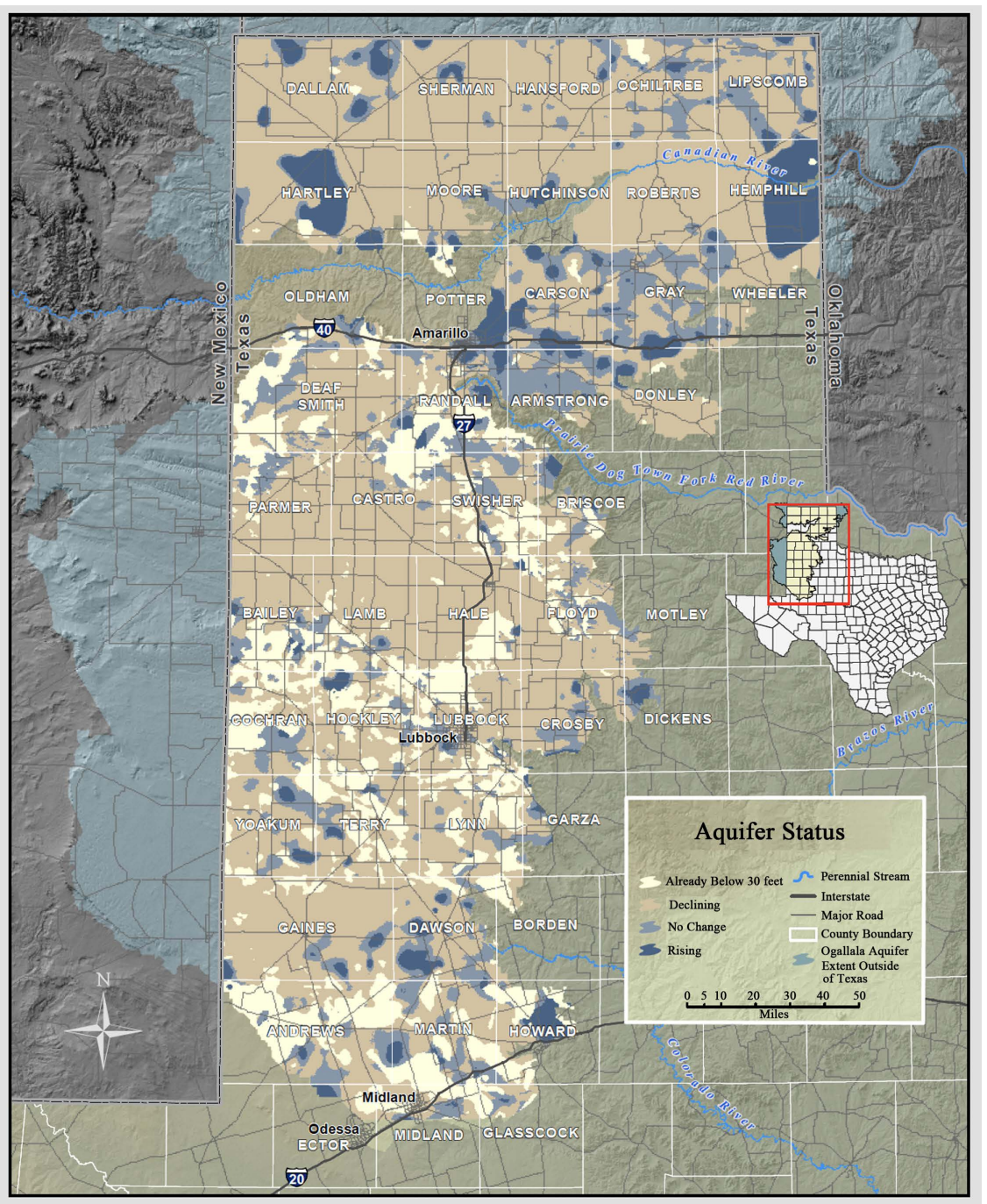

Figure 2. Status of the Ogallala aquifer on the Texas High Plains (Source: Center for Geospatial Technology, Texas Tech University. Available online at:

https://www.depts.ttu.edu/geospatial/center/Ogallala/MapSeries/PDFs/07 satThicknessSt atus 8x11.pdf).

crop need and, in some cases, the only option is to continuously irrigate the crop throughout the growing season [8]. Another irrigation system that recently has gained popularity in the THP is subsurface drip [18] [19]; however, in the THP this method does not always use rainwater as efficiently when compared to center pivot irrigation [20].

In the THP, the average decline of the depth to the water table of the Ogallala aquifer is about $0.3 \mathrm{~m} /$ year and on average has dropped about $15 \mathrm{~m}$ since measurements started in 1969 [21] [22]. The introduction of more efficient irrigation systems and attempts to monitor crop water use via evapotranspiration networks [9] have extended the lifespan of the Ogallala aquifer. However, an outcome not expected by the introduction of more efficient irrigation systems is the so-called "paradox of irrigation efficiency" where the rate of groundwater depletion actually increases due to irrigation [23]. This is explained by the fact that more effi- 
cient irrigation systems are installed in areas that were not previously irrigated and regions where irrigation had been discontinued are back in operation. The net effect on this use of efficient irrigation systems is that the groundwater depletion increases and the THP is in a state of transition moving from partial irrigation to dryland production.

There is no single definition of dryland farming [24]. For example, dryland farming has been defined as crop production without irrigation and $<500 \mathrm{~mm}$ of precipitation [25], or with scanty rainfall [26]. Another definition emphasized water conservation throughout the year [27] and included semiarid conditions [28]. In addition, the terms dryland and rainfed production are used interchangeably but are different and are distinguished by climate [24]. In this context, dryland farming refers to agriculture in regions where the lack of water limits crop production and is normally associated with a semiarid climate. Similarly, rainfed systems often deal with excess water during certain parts of the season but in humid climates. From our point view and for the agriculture of the THP we define dryland agriculture as crop production without irrigation and in a semiarid climate. The climate of the THP is classified as BSk, or cold semiarid in the Köppen-Geiger climate nomenclature [29].

The THP is a 41-county region that covers about $10^{4} \mathrm{~km}^{2}$ of land area extending from the Oklahoma state line on the east and north, to the New Mexico line on the west (Figure 2). In general, the rainfall pattern in this semiarid region decreases from north to south and from east to west. For example, in the north in Amarillo, Texas the long term (1892-2015) annual rainfall and standard deviation is $514 \pm 138 \mathrm{~mm}$ and about $200 \mathrm{~km}$ south in Lubbock, Texas the long term (1911-2019) annual rainfall and standard deviation is $472 \pm 159 \mathrm{~mm}$ (National Weather Service, https://www.weather.gov/). The annual rainfall distribution is variable and the monthly coefficient of variation $>60 \%$ with most of the rain falling during the growing season, from May to September [8]. The average elevation is about $0.9 \mathrm{~km}$ above sea level and most soils in cultivation are classified in three dominant soil series, i.e., Olton, Pullman and Amarillo [30] [31] [32]. This combination of rainfall and soil types result in a variety of production systems across the THP. For example, in the northern region the predominant production is grain-based with winter wheat (Triticum aestivum L.), corn (Zea mays L.) and grain sorghum (Sorghum bicolor (L.) Moench) and in the south the main crops are cotton (Gossypium hirsutum L.) and grain sorghum.

As the THP transitions to dryland cropping production systems the efficient use of rain is critical to assure an adequate water supply during the growing season [33] [34] [35]. The capture and storage of rainfall for any soil type is mainly a function of the rainfall rate and amount, and of soil physical properties that affect infiltration and runoff. Therefore, our objective was to explore, as first analysis, the annual water balance for a dry, average and wet year of rainfall for Lubbock, Texas and for two major (Pullman and Amarillo) soil series of the THP. Components of the water balance analyzed included the evaporation of water, infiltration of rain, drainage of water below the bottom of the profile and 
runoff. For this purpose, we used the mechanistic energy and water balance (ENWATBAL) model [36] [37] [38] to simulate the daily water balance for bare soil conditions. Our aim is to describe soil water holding capacity without crop transpiration and additional future work will explore the effect of these two-soil series on crop production using the DSSAT cropping system model [39].

\section{Materials and Methods}

\subsection{Simulations}

To address the objective of our study, simulations were done with the ENWATBAL model to calculate the daily water balance for a dry (2011), an average (2016) and wet (2015) year of rainfall for a soil in a Pullman (fine, mixed, thermic, Torrertic Paleustoll) and an Amarillo (fine-loamy, mixed, thermic, Aridic Paleustalf) series. For these simulations we used as input hourly measured weather variables for a location near Lubbock, Texas. A brief description of the model, including theory, inputs and soil geometry follow.

\subsection{ENWATBAL Model}

The ENWATBAL (ENergy and WATer BALance) model is a one-dimensional and mechanistic representation of a soil, where processes are based on principles of the conservation of mass and energy. The simulation model, ENWATBAL, used in our analysis is described in detail by [36] [37]. We used the version of the simulation model written in compiled BASIC as given by [38]. The ENWATBAL model calculates the energy and water balance of a soil surface by simultaneously solving equations that calculate the fluxes of water and heat in a soil profile. In the model, the upper boundary condition is defined at a screen height of $2 \mathrm{~m}$, i.e., height above the soil surface where weather variables are measured. The lower boundary is the bottom of the profile, where we assume unit hydraulic gradient, i.e., $\mathrm{d} \psi / \mathrm{d} x=1$, where $\psi$ is the soil water potential (m) and $x$ is the soil vertical distance $(\mathrm{m})$. The fluxes of water and heat are calculated as follows.

The flux of water is calculated from Darcy's Law and the equation of continuity:

$$
\partial \theta_{v} / \partial t=\partial / \partial x\left(K\left(\theta_{v}\right)\left(\partial \psi_{\text {total }}\right) / \partial x\right)
$$

where $\theta_{v}$ is the soil volumetric water content $\left(\mathrm{m}^{3} / \mathrm{m}^{3}\right), t$ is time (s), $x$ is the vertical distance in the soil profile $(\mathrm{m}), K\left(\theta_{v}\right)$ is the unsaturated hydraulic conductivity $(\mathrm{m} / \mathrm{s})$ a function of $\theta_{v}$, and $\partial \psi_{\text {total }} / \partial x$ is the total vertical hydraulic potential gradient $(\mathrm{m} / \mathrm{m})$. Normally, soil water potential values are expressed in SI units of $\mathrm{Pa}(\mathrm{MPa}$ and $\mathrm{kPa}$ ); however, in our case we use the $\mathrm{m}$ as the unit of hydraulic head, as it simplifies the unit of the gradient $(\mathrm{d} \psi / \mathrm{d} x)$ to $\mathrm{m} / \mathrm{m}$.

The flux of soil heat is calculated from Fourier's Law and the equation of continuity:

$$
C_{s}(\partial T / \partial t)=\partial / \partial x(\lambda(T) \partial T / \partial x)
$$


where $C_{s}$ is soil volumetric heat capacity $\left(\mathrm{J} / \mathrm{m}^{3} \cdot{ }^{\circ} \mathrm{C}\right), T$ is the soil temperature $\left({ }^{\circ} \mathrm{C}\right), \lambda(T)$ is the soil thermal conductivity $\left(\mathrm{W} / \mathrm{m} \cdot{ }^{\circ} \mathrm{C}\right)$ a function of soil temperature $T\left({ }^{\circ} \mathrm{C}\right)$ and $\partial T / \partial x$ is the vertical soil temperature gradient $\left({ }^{\circ} \mathrm{C} / \mathrm{m}\right)$.

The evaporation of water at the soil surface is calculated from the energy balance and the turbulent transport of air above the soil surface, as follows:

$$
R_{n}+L \times E+A+G=0,
$$

where $R_{n}$ is the net irradiance, $L E$ is the evaporative flux, $A$ is the sensible heat flux to the air, and $G$ is the soil heat flux. All terms in Equation (3) have units of $\mathrm{W} / \mathrm{m}^{2}$ and each term of the energy balance is in reference to the soil surface so that during daytime hours, $R_{n}$ is positive, $E$ is negative, and both $A$ and $G$ are generally negative.

The aerodynamic resistance $r_{a}(\mathrm{~s} / \mathrm{m})$ is calculated as:

$$
r_{a}=\left[\ln \left(2 / Z_{o}\right)\right]^{2} /\left(0.16 \times u_{z}\right)
$$

where $Z_{o}$ is the surface roughness $(\mathrm{m})$, and $u_{z}$ is the measured windspeed $(\mathrm{m} / \mathrm{s})$ at a screen height of $2 \mathrm{~m}$ above the soil surface. The $r_{a}$ is corrected $\left(r_{c}\right)$ for stability $\left(S_{t}\right)$ as:

$$
r_{c}=r_{a} \times S_{t}
$$

The stability factor $\left(S_{t}\right)$ is calculated as:

$$
S_{t}=1 /\left(1-10 \times R_{i}\right)
$$

where $R_{i}$ is Richardson's number [40], defined by:

$$
R_{i}=\left[9.81 \times\left(2-Z_{o}\right) \times\left(T_{a}-T_{s}\right)\right] /\left[\left(T_{a}+273.16\right) \times u_{z}^{2}\right]
$$

where $T_{a}$ is the measured air temperature $\left({ }^{\circ} \mathrm{C}\right)$ at a screen height of $2 \mathrm{~m}$, and $T_{s}$ is the unknown soil surface temperature $\left({ }^{\circ} \mathrm{C}\right)$. This method to calculate $r_{c}$ is given by [41], and used by [42] [43], and others.

The latent heat transfer $(L \times E)$ in Equation (3) is calculated from:

$$
L \times E=L \times\left[\left(\chi_{s}-\chi_{a}\right) / r_{c}\right]
$$

where $L$ is the latent heat of vaporization $(\mathrm{J} / \mathrm{kg}), \chi_{s}$ is the absolute humidity at the soil surface $\left(\mathrm{kg} / \mathrm{m}^{3}\right)$ and $\chi_{a}$ is measured absolute humidity of the air temperature $\left(\mathrm{kg} / \mathrm{m}^{3}\right)$ at a screen height of $2 \mathrm{~m}$. The sensible heat flux $(A)$ between the soil surface and air above it is calculated from:

$$
A=\left[\left(T_{s}-T_{a}\right) / r_{c}\right] \times C_{a}
$$

where $T_{s}$ is unknown soil surface temperature $\left({ }^{\circ} \mathrm{C}\right), T_{a}$ is the measured air temperature $\left({ }^{\circ} \mathrm{C}\right)$, and $C_{a}$ is the volumetric heat capacity of the air $\left(\mathrm{J} / \mathrm{m}^{3} \cdot{ }^{\circ} \mathrm{C}\right)$. The last term of the energy balance in Equation (3), the soil heat flux $(G)$ is calculated from:

$$
G=-\lambda(T) \times(\partial T / \partial x)
$$

where $\lambda(T)$ is the soil thermal conductivity $\left(\mathrm{W} / \mathrm{m} \cdot{ }^{\circ} \mathrm{C}\right)$ a function of the soil temperature $(T)$ in ${ }^{\circ} \mathrm{C}$, and $\partial T / \partial x$ is the vertical soil temperature gradient 
$\left({ }^{\circ} \mathrm{C} / \mathrm{m}\right)$.

In ENWATBAL the evaporative flux is solved from a combination of the surface energy balance and an aerodynamic model of the turbulent air above the soil surface. The unknown value of the surface energy balance is the soil surface temperature $\left(T_{s}\right)$ in Equations (7) and (9) and this value is found by iteration until the surface energy balance of zero is numerically met. At each time step $(\Delta t)$, ENWATBAL, begins by finding, from the previous values of the soil water content and temperature of each soil layer, the corresponding soil hydraulic potentials and the water and conductivity values. These are the so-called soil hydraulic properties that include the soil-water pressure potential $(\psi)$ release curve, i.e., $\psi\left(\theta_{v}\right)$, and the unsaturated soil hydraulic conductivity, i.e., $K\left(\theta_{v}\right)$. The $\psi\left(\theta_{v}\right)$ is measured using well established laboratory procedures [44] and $K\left(\theta_{v}\right)$ is calculated using measured values of the saturated hydraulic conductivity $\left(K_{\text {sat }}\right)$ and $\psi\left(\theta_{v}\right)$ with the methods of [45] and [46]. Thereafter, the interlayers fluxes for heat and water are calculated, except for the values at the soil surface, which as previously mentioned are calculated from Equation (3), the energy balance equation. Once the surface temperature $\left(T_{s}\right)$ is known the evaporation of water from the soil surface is calculated. The soil heat flux, $G$ (Equation (10)) is also calculated from the known value of $T_{s}$. The soil thermal conductivity is calculated from method given by [47], which is based on soil texture. When it rains, the evaporation rate at the soil surface is modified by the infiltration of rain and detention capacity, i.e., the depth to store water on the soil surface. For additional details the reader is referred to [36] [37] and to [38].

\subsection{Inputs to the Model}

The inputs to the model are categorized as time-dependent variables, constants, soil hydraulic functions, and initial values. The time-dependent inputs are the weather variables, and in our simulations, we used hourly values of solar irradiance, air and dewpoint temperature, and wind-speed all measured at a screen height of $2 \mathrm{~m}$. In our simulations we used hourly weather data for a dry year (2011) with $190 \mathrm{~mm}$ of rain, an average year (2016) with $449 \mathrm{~mm}$ of rain and a wet year (2015) with $669 \mathrm{~mm}$ of rain. The values used were derived from sub-daily meteorological data from the West Texas Mesonet [48] weather station at Abernathy, Texas, which is located $\sim 30 \mathrm{~km}$ north of Lubbock, Texas.

Constant input values are the screen height of the meteorological measurements of $2 \mathrm{~m}$, the roughness parameter $\left(Z_{o}\right)$ in Equation (4) of $0.01 \mathrm{~m}$, the saturated hydraulic conductivity $\left(K_{\text {sat }}\right)$ and porosity $(f)$ shown in Table 1 . These values are given for the two depths of the Pullman and the Amarillo soil series [32].

Soil functions used as input are the soil hydraulic properties, i.e., soil-water retention curve and unsaturated hydraulic conductivity, the soil thermal conductivity and the relationship between albedo and the surface soil water content. In our simulations we used the albedo vs. soil water content function given by [36]. The soil geometry, soil hydraulic properties and initial values used as input are described next. 
Table 1. Input values of measured saturated hydraulic conductivity $\left(K_{\text {sat }}\right)$ and calculated porosity $(f)$ for a Pullman and an Amarillo soil series used in simulations. Also given are measured values of sand, clay and soil bulk density $\left(\rho_{b}\right)$. Values given are the average \pm standard deviation (from [32]).

\begin{tabular}{|c|c|c|c|c|}
\hline \multirow{2}{*}{$\begin{array}{c}\text { Soil Property } \\
\text { Soil Depth [m] }\end{array}$} & \multicolumn{2}{|c|}{ Pullman Series } & \multicolumn{2}{|c|}{ Amarillo Series } \\
\hline & $0.0-0.3$ & $>0.3$ & $0.0-0.4$ & $>0.4$ \\
\hline$K_{\text {sat }} \times 10^{-6}[\mathrm{~m} / \mathrm{s}]$ & $12.8 \pm 0.30$ & $0.22 \pm 0.02$ & $21.4 \pm 0.30$ & $12.6 \pm 0.3$ \\
\hline Porosity $f[\%]^{\star}$ & 55 & 44 & 47 & 40 \\
\hline Sand [\%] & $36.7 \pm 2.4$ & $28.5 \pm 2.1$ & $75.1 \pm 1.7$ & $57.3 \pm 2.6$ \\
\hline Clay [\%] & $41.0 \pm 0.8$ & $49.5 \pm 1.8$ & $21.2 \pm 0.7$ & $35.3 . \pm 2.7$ \\
\hline$\rho_{b}\left[\mathrm{Mg} / \mathrm{m}^{3}\right]$ & $1.20 \pm 0.08$ & $1.49 \pm 0.09$ & $1.40 \pm 0.10$ & $1.60 \pm 0.10$ \\
\hline
\end{tabular}

\subsection{Soil Geometry and Input Values}

In the model, the soil profile is divided into layers of different thickness and for each layer an initial value, i.e., at time $=0$, of soil temperature $\left(T,{ }^{\circ} \mathrm{C}\right)$ and soil water content $\left(\theta_{b} \mathrm{~m}^{3} / \mathrm{m}^{3}\right)$ is assigned. The thickness of the first soil layer is important as the evaporative fluxes of water and heat at the soil surface is calculated from the midpoint value of this soil layer. An example of the geometry and initial conditions of the soil profile for an Amarillo soil with assumed values of $T$ and $\theta_{v}$ is shown in Table 2. The assigned thickness of the first soil layer was 5 $\mathrm{mm}$, as suggested by [37], which showed that this value was adequate to correctly calculate soil water evaporation. The soil profile was divided into 24 layers for a soil depth of $2.1 \mathrm{~m}$. Further, the profile was divided into two horizons. The first horizon $A$ was $0.45 \mathrm{~m}$ in depth and the second horizon $B$ was $1.65 \mathrm{~m}$. Each horizon was characterized with specific soil hydraulic properties, i.e., soil water potential $(\psi)$ and unsaturated hydraulic conductivity $(K)$, both as a function of soil volumetric water content $\left(\theta_{v}\right)$. In our simulations we used the values given by [32] for a Pullman and for an Amarillo soil series, shown in Figure 3 for the soil water potential and in Figure 4 for the unsaturated hydraulic conductivity.

\section{Results and Discussion}

The annual water balance for three yearly rainfall totals that represent a dry year with $189 \mathrm{~mm}$, an average year with $449 \mathrm{~mm}$ and a wet year with $669 \mathrm{~mm}$ of rain and calculated with the ENWATBAL model for an Amarillo and a Pullman soil series are given in Table 3. Hereafter and for convenience the three simulated rainfall scenarios are referred to respectively as dry, average and wet. These results represent a first analysis of the annual water balance dynamics of two major soil series in the Texas High Plains and their implication, for dryland production. For this goal, we used the ENWATBAL model that has been tested for a variety of crops and soil types by mainly comparing calculated and measured values of soil water and crop evaporation [37]-[53] and others. Therefore, in our analysis we assumed that the calculated values obtained with the ENWATBAL 
Table 2. Geometry of the soil profile and initial values of water content $\left(\theta_{v}\right)$ and temperature $(T)$ used in simulations for an Amarillo soil series. Soil layers number 1 - $11(0$ $0.45 \mathrm{~m}$ ) and soil layers number 12 - 24 (0.45 - 2.1 m) define Horizon A and B, respectively. Each horizon has specific soil hydraulic properties as given by [32] and shown in Figure 3 and Figure 4.

\begin{tabular}{|c|c|c|c|c|c|c|}
\hline Soil Layer \# & $\begin{array}{c}\text { Layer } \\
\text { Thickness } \\
\text { [m] }\end{array}$ & $\begin{array}{l}\text { Vertical Distance } \\
\text { Surface to } \\
\text { mid-layer [mm] }\end{array}$ & $\begin{array}{l}\text { Cumulative } \\
\text { Depth }[\mathrm{m}]\end{array}$ & $\begin{array}{l}\text { Initial } \theta_{V} \\
{\left[\mathrm{~m}^{3} / \mathrm{m}^{3}\right]}\end{array}$ & $\begin{array}{c}\text { Initial } T \\
{\left[{ }^{\circ} \mathrm{C}\right]}\end{array}$ & Horizon \\
\hline 1 & 0.005 & 2.5 & 0.005 & 0.10 & 25.0 & A \\
\hline 2 & 0.010 & 10.0 & 0.015 & 0.10 & 25.0 & A \\
\hline 3 & 0.010 & 20.0 & 0.025 & 0.10 & 25.0 & A \\
\hline 4 & 0.025 & 37.5 & 0.050 & 0.10 & 25.0 & A \\
\hline 5 & 0.025 & 62.5 & 0.075 & 0.10 & 25.0 & A \\
\hline 6 & 0.025 & 87.5 & 0.100 & 0.10 & 25.0 & A \\
\hline 7 & 0.050 & 125.0 & 0.150 & 0.15 & 25.0 & A \\
\hline 8 & 0.050 & 175.0 & 0.200 & 0.15 & 25.0 & A \\
\hline 9 & 0.050 & 225.0 & 0.250 & 0.15 & 25.0 & A \\
\hline 10 & 0.010 & 300.0 & 0.350 & 0.15 & 25.0 & A \\
\hline 11 & 0.010 & 400.0 & 0.450 & 0.20 & 25.0 & A \\
\hline 12 & 0.015 & 457.5 & 0.475 & 0.20 & 25.0 & B \\
\hline 13 & 0.025 & 477.5 & 0.500 & 0.20 & 25.0 & B \\
\hline 14 & 0.025 & 502.5 & 0.550 & 0.25 & 25.0 & B \\
\hline 15 & 0.050 & 540.0 & 0.600 & 0.25 & 25.0 & B \\
\hline 16 & 0.050 & 590.0 & 0.700 & 0.30 & 25.0 & B \\
\hline 17 & 0.050 & 665.0 & 0.800 & 0.30 & 25.0 & B \\
\hline 18 & 0.010 & 765.0 & 0.950 & 0.30 & 25.0 & B \\
\hline 19 & 0.015 & 890.0 & 1.100 & 0.30 & 25.0 & B \\
\hline 20 & 0.150 & 1040.0 & 1.300 & 0.30 & 25.0 & B \\
\hline 21 & 0.200 & 1215.0 & 1.500 & 0.30 & 25.0 & B \\
\hline 22 & 0.200 & 1415.0 & 1.700 & 0.30 & 25.0 & B \\
\hline 23 & 0.200 & 1615.0 & 1.900 & 0.30 & 25.0 & B \\
\hline 24 & 0.200 & 1815.0 & 2.100 & 0.30 & 25.0 & B \\
\hline
\end{tabular}

Table 3. Annual water balance for a dry (2011), average (2016) and wet (2015) year of rainfall for an Amarillo (Am) and a Pullman (Pull) soil series calculated with the ENWATBAL model.

\begin{tabular}{cccccccccc}
\hline \multirow{2}{*}{ Year } & Rain $[\mathrm{mm}]$ & \multicolumn{2}{c}{$\begin{array}{c}\text { Evaporation } \\
{[\mathrm{mm}]}\end{array}$} & \multicolumn{2}{c}{$\begin{array}{c}\text { Infiltration } \\
{[\mathrm{mm}]}\end{array}$} & $\begin{array}{c}\text { Drainage } \\
{[\mathrm{mm}]}\end{array}$ & \multicolumn{2}{c}{$\begin{array}{c}\text { Runoff } \\
(\mathrm{mm})\end{array}$} \\
\cline { 3 - 10 } & & Am & Pull & Am & Pull & Am & Pull & Am & Pull \\
\hline 2011 (Dry) & 189 & 222 & 125 & 189 & 189 & 11 & 0 & 0 & 0 \\
2016 (Avg) & 449 & 488 & 340 & 449 & 449 & 11 & 0 & 0 & 14 \\
2015 (Wet) & 669 & 700 & 529 & 669 & 688 & 11 & 0 & 0 & 5 \\
\hline
\end{tabular}




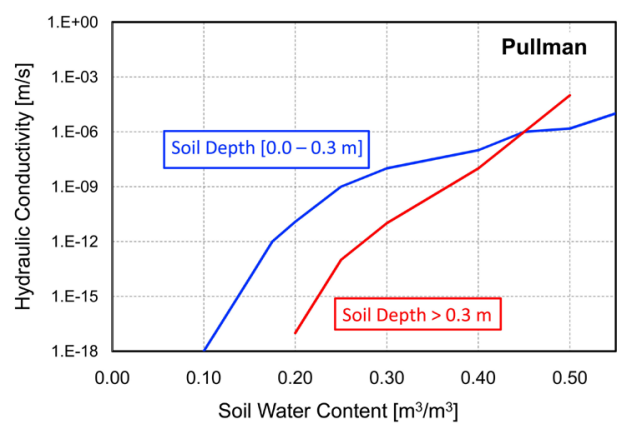

(a)

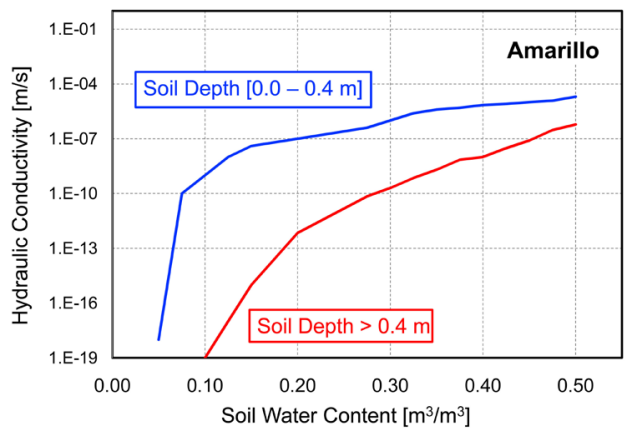

(b)

Figure 3. Hydraulic conductivity $(\mathrm{m} / \mathrm{s})$ as a function of soil water content $\left(\mathrm{m}^{3} / \mathrm{m}^{3}\right)$. (a) Soil depth of $0.0-0.3 \mathrm{~m}$ and a soil depth $>0.3 \mathrm{~m}$ for a Pullman soil, and (b) soil depth of $0.0-0.4 \mathrm{~m}$ and a depth $>0.4 \mathrm{~m}$ for an Amarillo soil (from [32]).

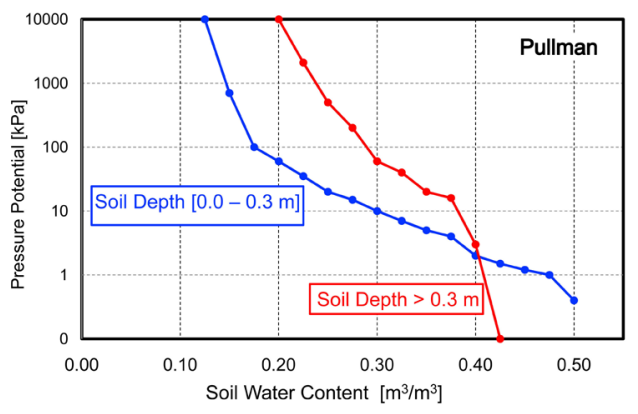

(a)

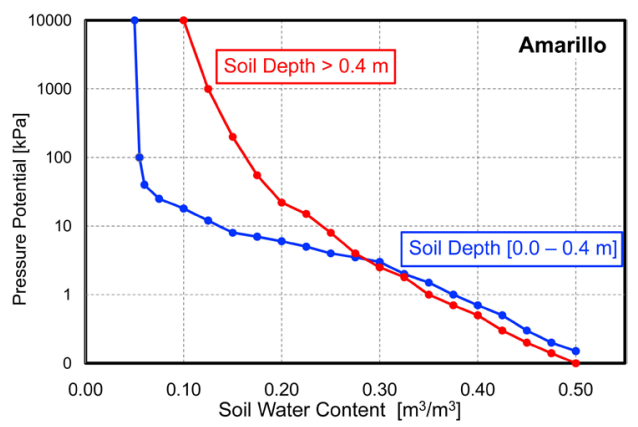

(b)

Figure 4. Pressure potential $(\mathrm{kPa})$ as a function of soil water content $\left(\mathrm{m}^{3} / \mathrm{m}^{3}\right)$. (a) Soil depth of $0.0-0.3 \mathrm{~m}$ and a soil depth $>0.3 \mathrm{~m}$ for a Pullman soil, and (b) soil depth of 0.0 $0.4 \mathrm{~m}$ and a depth $>0.4 \mathrm{~m}$ for an Amarillo soil (from [32]). 
model are qualitatively correct; moreover, results are discussed by comparing both the absolute and relative values from each of the two-soil series. The components of the water balance are evaporation, infiltration, drainage and runoff of water and the contribution of each element is discussed below.

\subsection{Annual Water Balance}

For all three years, dry, average and wet, the annual evaporation of water was higher in the Amarillo soil series compared to the Pullman and this difference decreased with increasing rainfall (Table 3). For example, on the dry year the evaporation of water from the Amarillo soil was $222 \mathrm{~mm}$ vs. $125 \mathrm{~mm}$ from the Pullman, i.e., $40 \%$ less. Similarly, on the wet year the water evaporation in the Amarillo soil was $700 \mathrm{~mm}$ compared to $529 \mathrm{~mm}$ on the Pullman soil, i.e., a difference of $20 \%$. Another noteworthy difference in the total evaporation of water between the two-soil series is that in the Amarillo series all rainfall was lost to evaporation. Further, in the Amarillo soil series stored water in the soil profile also contributed to the total annual evaporative loss. On an annual basis, no stored soil water in the Pullman series contributed to the evaporative loss of water.

A major difference between the two-soil series was the capability of the Pullman soils to store rainfall in the profile. For example, in the dry year, $64 \mathrm{~mm}$ of rain was stored in the soil profile, which is $34 \%$ of the total rainfall. In the average year, $109 \mathrm{~mm}$ of the rain (24\% of rainfall) and in the wet year $140 \mathrm{~mm}$ of rain (21\% of total rainfall) was stored in the soil. The implications of this storage of rainfall for dryland crop production in the semiarid Texas High Plains are important. From these results we can conclude that regardless of rainfall amount, soils in the Pullman series have an increased ability to store rainfall. Further, this storage could be enhanced using conservation-bench and level-bench terraces, contour and blocked furrows and minimum tillage practices as suggested by [54]. Soils in the Pullman series are mainly in the northern region of the THP and cover about $1.5 \times 10^{6}$ ha. Furthermore, these results suggest that the storage of rainfall in soils of the Amarillo series will be challenging and will require incorporation of best management practices, such as surface residue and minimum tillage to maximize rainfall storage [55] [56].

A difficulty in using surface residues to conserve water is that in many cases this practice results in decreasing water that may be stored in the soil as the water used to establish the residue exceeds the amount of water stored in the soil [52] [57] [58] [59]. However, there are other benefits associated with the surface residue such as increasing infiltration [57] and promoting biophysical and chemical soil properties to enhance soil health [60] [61]. Currently, this is an important topic of research to determine appropriate types of residue to use for dryland production in the THP and particularly in areas where the predominant soil series is the Amarillo.

The calculated differences in the evaporative losses between the two-soil series and for the same environmental conditions are due to their respective soil hy- 
draulic properties (Figure 3 and Figure 4). For example, in the Amarillo soil series, in the surface $0.4 \mathrm{~m}$ layer, the soil water content between 0.20 to $0.50 \mathrm{~m}^{3} / \mathrm{m}^{3}$ is held over a relatively narrow range of pressure potential ( 0 to $10 \mathrm{kPa}$ ); whereas, for the Pullman soil series and for the same range of soil water content the pressure potential varies from 0 to $100 \mathrm{kPa}$, i.e., an order of magnitude larger, and this is due to the higher clay content on the surface layer. Further, soils in Pullman series in the upper soil layer $(0.3 \mathrm{~m})$ have a porosity of $55 \%$ compared to $47 \%$ for the Amarillo soil, indicating a higher storage capacity. These physical properties affect infiltration and water storage capacity [57] [58].

Results of the remaining components of the water balance, i.e., infiltration, drainage and runoff are shown in Table 3. The calculated infiltration of rainfall indicated no differences between the two-soil series and for any of the three rainfall scenarios. In our simulations and for the calculation of drainage we assumed unit hydraulic gradient, i.e., $\mathrm{d} \psi / \mathrm{d} x=1$, at the lower boundary of the soil profile, which was at a depth of about $2 \mathrm{~m}$ from the soil surface. This assumption netted $11 \mathrm{~mm}$ of annual drainage in the Amarillo soil and no drainage in the Pullman soil series. Finally, the last component of the annual water balance was runoff and results indicated no runoff for the Amarillo soil series and runoff amounts of $14 \mathrm{~mm}$ for the Pullman soil series for an average rainfall and $5 \mathrm{~mm}$ for the wet year. The calculation of water runoff from a soil surface is affected by many variables, e.g., rainfall amount and rate, antecedent soil water content, particularly in the surface $0.2 \mathrm{~m}$, and detention capacity. A detailed analysis with different rainfall intensities, initial soil water contents and detention capacities and their effect on infiltration and runoff was beyond the scope of this paper and is the subject of a forthcoming article.

\subsection{Daily Water Evaporation}

Examples of the daily evaporation of water from a bare soil and calculated with the ENWATBAL model for the entire simulation period for the Pullman soil series for both the wet and dry year are shown in Figure 5 and in Figure 6 for the Amarillo soil series. The daily evaporation of water is plotted as a negative number to indicate a loss; whereas, the corresponding daily rainfall is shown as a positive number to indicate again. The corresponding cumulative rainfall and cumulative evaporation for the dry year for both soil series is plotted in Figure 7 (a) and for the wet year, the cumulative values are plotted in Figure 7 (c). The net gain or loss of water, i.e., rainfall-evaporation, resulting in water stored in the profile for both soil series is plotted in Figure 7(b) for the dry year and in Figure 7(d) for the wet year. To further highlight the dynamic nature of the process of daily evaporation from a bare soil we selected 70 days, from day of year (DOY) 100 to DOY 170, for the wet year and for the Pullman soil series (Figure 8). The corresponding daily rainfall for the 70-day period is shown as a histogram (Figure 8). On the other extreme as an example and to illustrate the evaporation of water from a bare soil under very dry conditions we selected a 30-day period, from DOY 160 to DOY 190, for both soil series and these results 


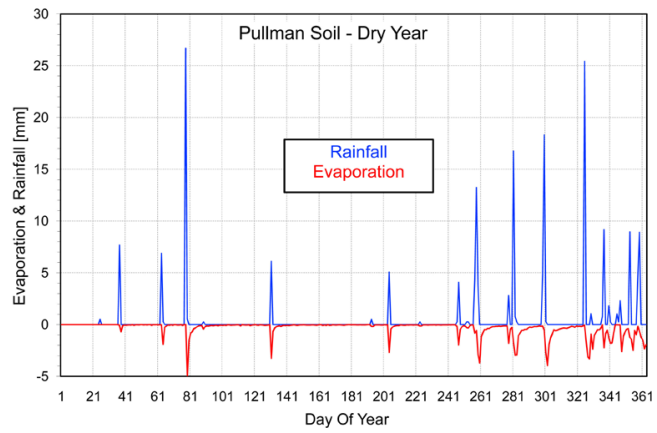

(a)

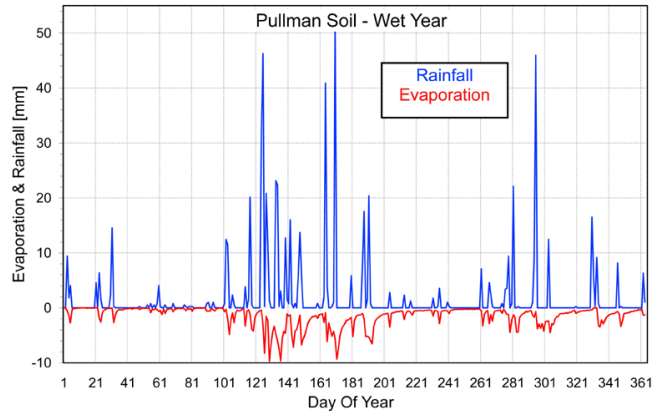

(b)

Figure 5. Calculated daily water evaporation simulated with the ENWATBAL model and measured rainfall as a function of day of year for the Pullman soil series on the (a) dry; and (b) on the wet year. The rainfall is shown as positive values and the evaporation is given as negative values.

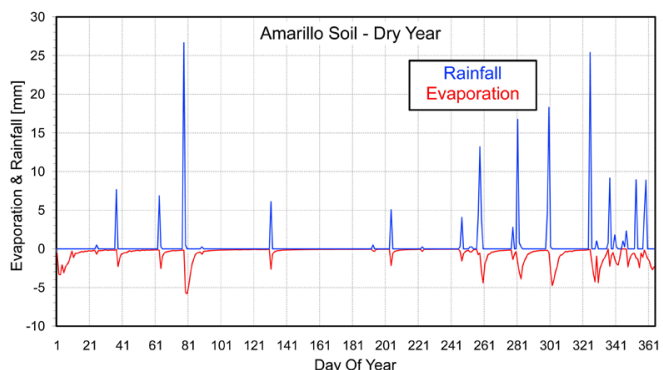

(a)

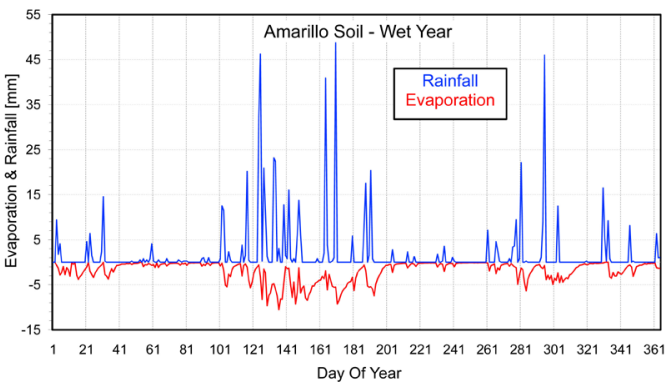

(b)

Figure 6. Calculated daily water evaporation simulated with the ENWATBAL model and measured rainfall as a function of day of year for the Amarillo soil series on the (a) dry; and (b) the wet year. The rainfall is shown as positive values and the evaporation is given as negative values. 


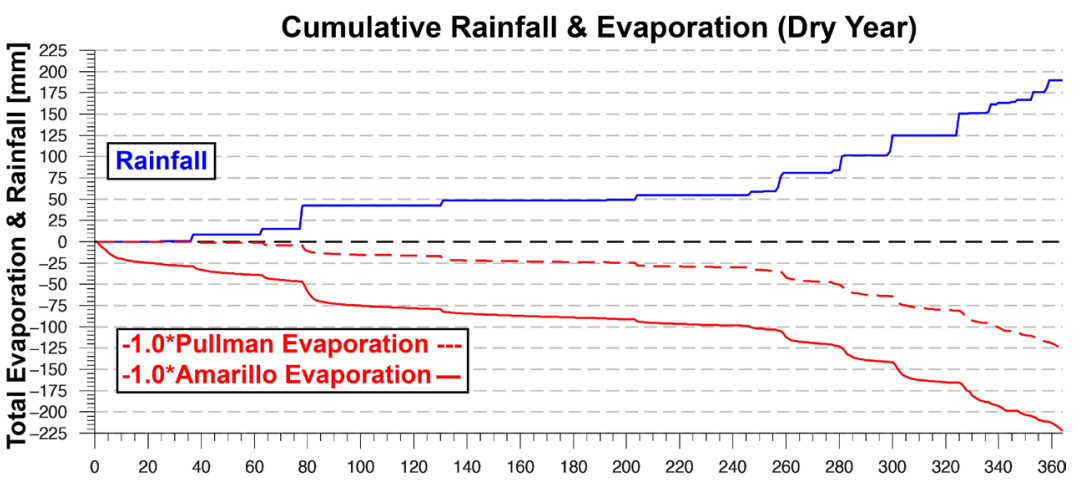

(a)

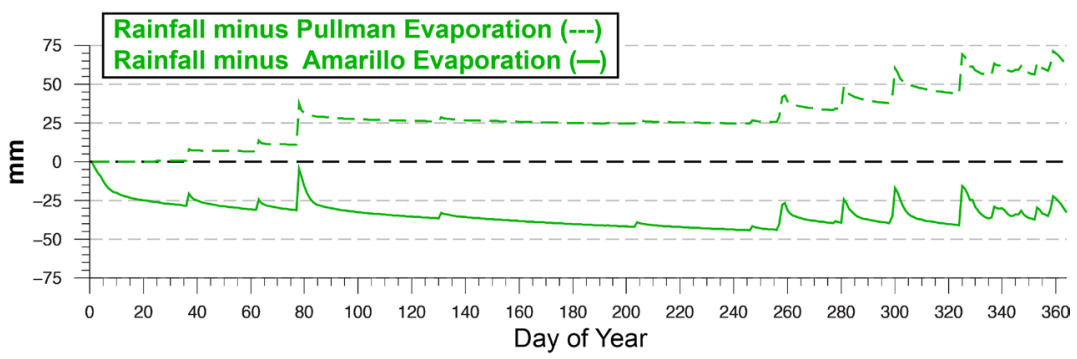

(b)

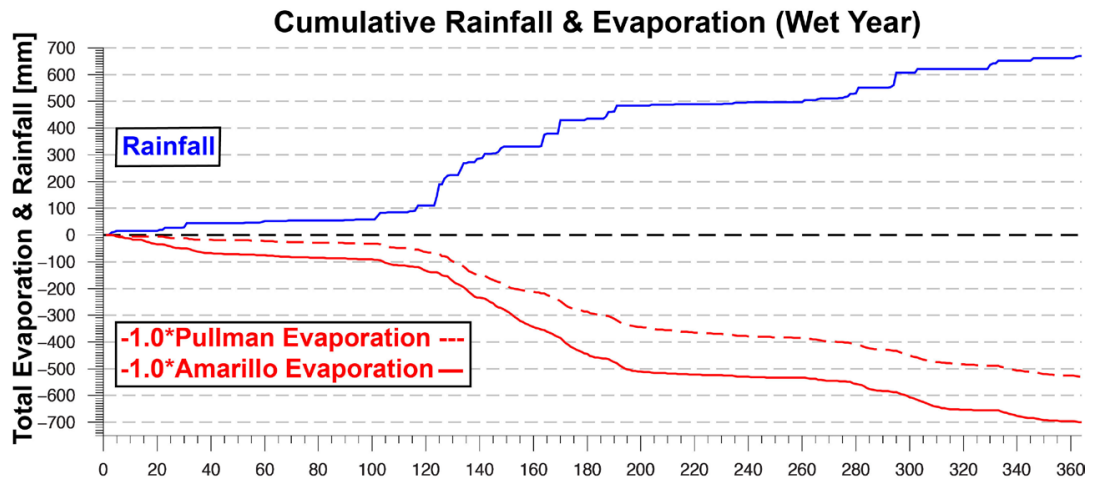

(c)

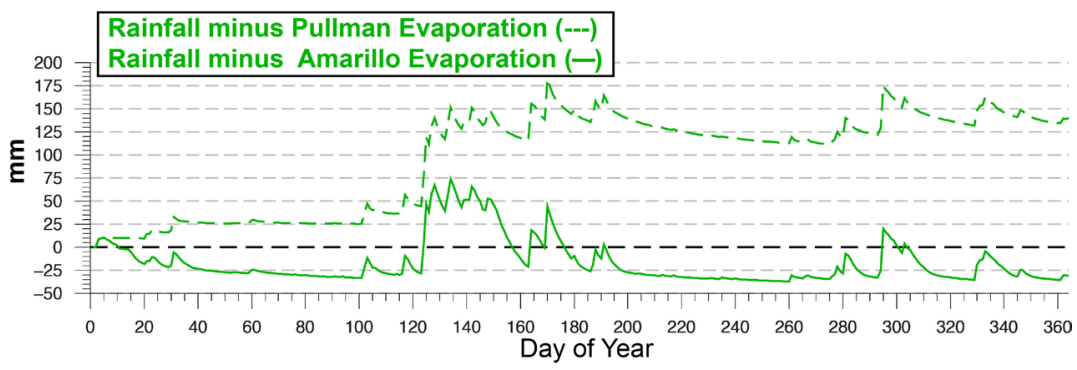

(d)

Figure 7. (a) Cumulative daily rainfall and evaporation for the dry year for the Pullman and Amarillo series; (b) Daily net storage of water in the profile (Rainfall-Evaporation) for the dry year and for both soil series; (c) Cumulative daily rainfall and evaporation for the wet year for the Pullman and Amarillo series; (d) Daily net storage of water in the profile (Rainfall-Evaporation) for the wet year and for both soil series. Rainfall minus Evaporation is given by dashed lines (- - -) for the Pullman and by solid lines ( - ) for the Amarillo series. 


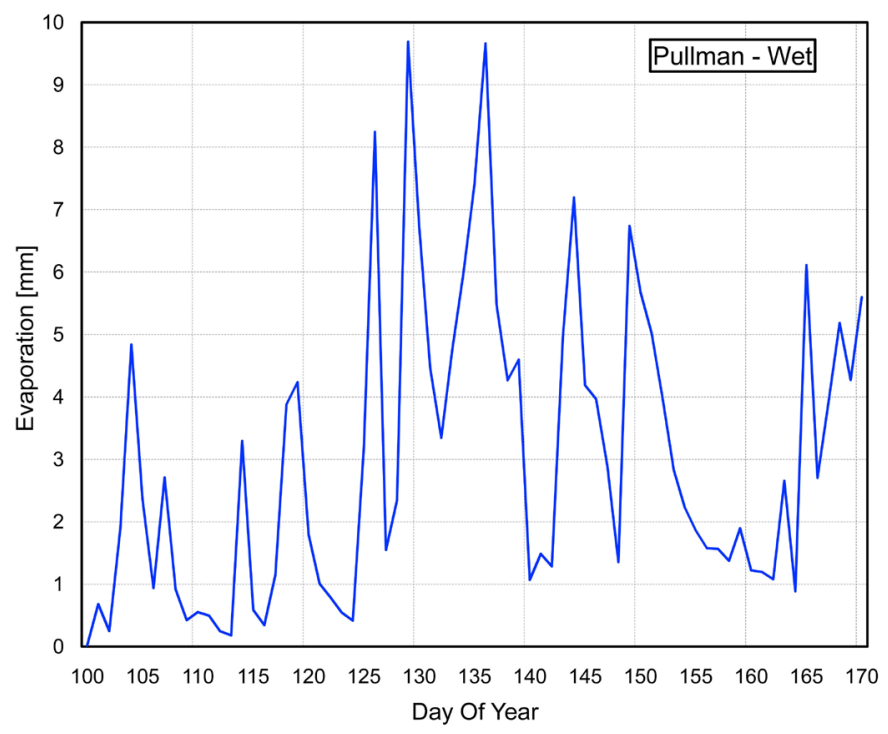

(a)

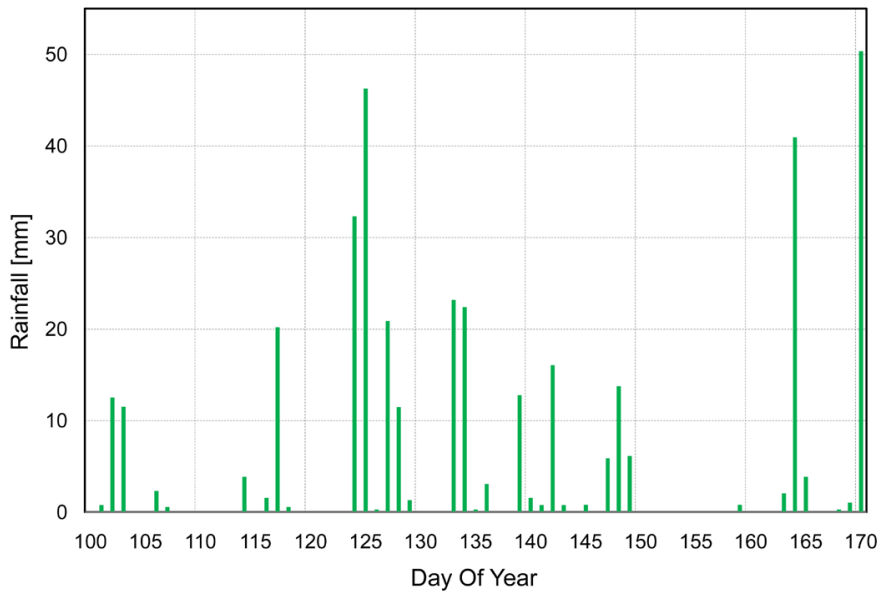

(b)

Figure 8. Calculated daily water evaporation for a period of 70 days, from DOY 100 to DOY 170 for the Pullman soil during the wet year. (a) The daily evaporation is shown in the upper portion, and (b) the corresponding rainfall for the same time period is shown in the lower portion of the figure.

are shown in Figure 9. No rainfall occurred during this time period on the dry year. Also shown is the daily evaporation for both soil series in the wet year with $152 \mathrm{~mm}$ of rain (Figure 9).

As expected, the high peaks of evaporative water loss from the soil surface occur immediately after a rainfall and the magnitude, rate and duration, is a function of the prevailing environmental conditions. For example, in the Pullman soil series and in the dry year (Figure 5 ) the largest loss of water to evaporation $(5.1 \mathrm{~mm} / \mathrm{d})$ occurred on DOY 79 following a $27 \mathrm{~mm}$ rain the day before. Thereafter, the daily evaporation did not exceed $4 \mathrm{~mm} / \mathrm{d}$ as the summer months were extremely dry, with about $12 \mathrm{~mm}$ of rain from DOY 122 to DOY 244, and a corresponding $22 \mathrm{~mm}$ of cumulative evaporation. In the wet year, the daily 

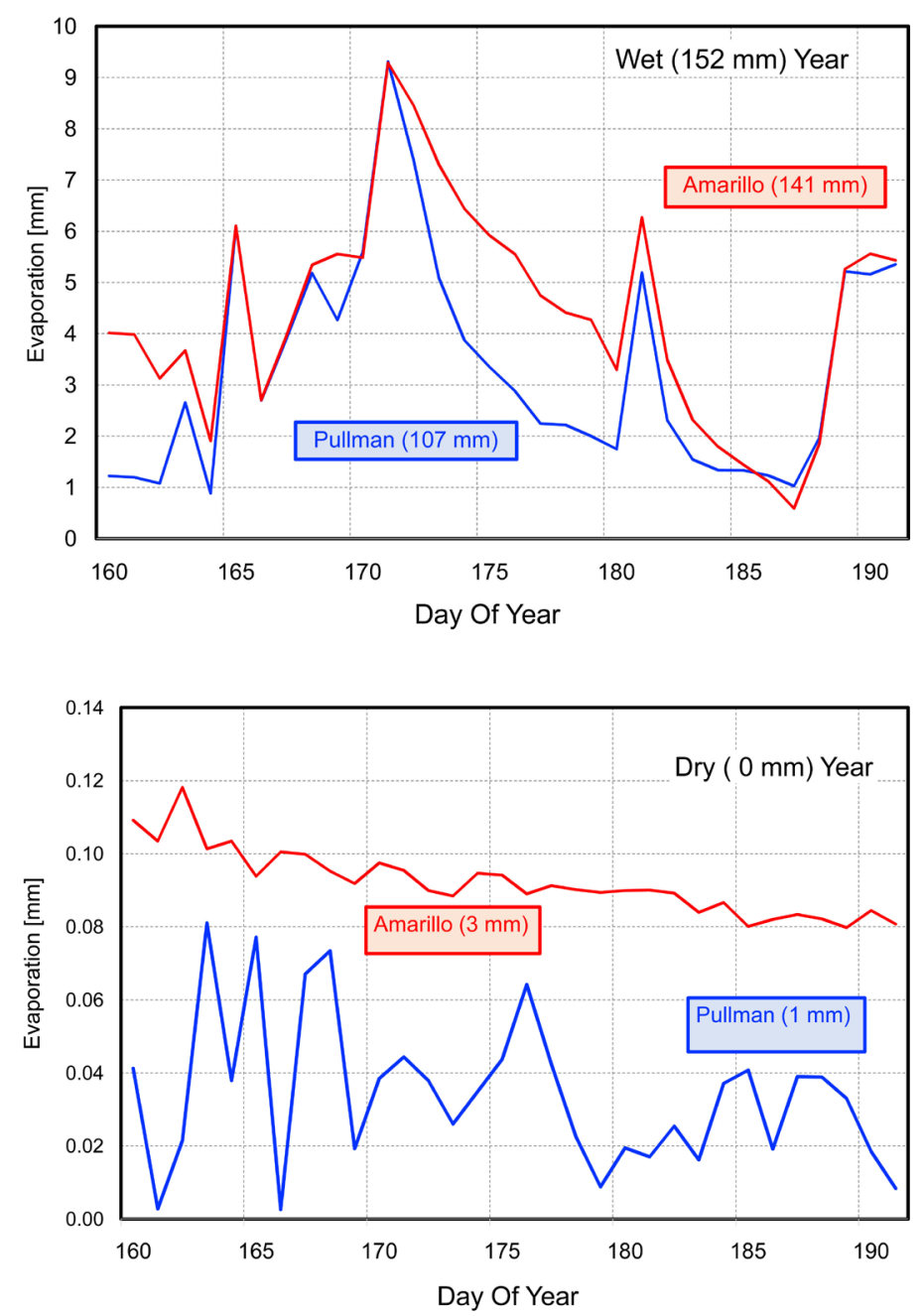

Figure 9. Calculated daily water evaporation from DOY 160 - 190 for the Pullman and Amarillo soil series for the wet and dry year. For the wet year the total rain was $152 \mathrm{~mm}$ and there was no rain during the dry year. The cumulative evaporation of water for the wet year was $141 \mathrm{~mm}$ for the Amarillo and $107 \mathrm{~mm}$ for the Pullman series. In the dry year the cumulative evaporation was $3 \mathrm{~mm}$ for the Amarillo and $1 \mathrm{~mm}$ for the Pullman series.

evaporative loss was close to $10 \mathrm{~mm} / \mathrm{d}$ on three days of the summer (DOY 126, 129 and 136) and over this 10-day period the total rainfall was $83 \mathrm{~mm}$ (Figure 5). The total rainfall during the summer months (May to August) was $390 \mathrm{~mm}$. The dry year is an example of a catastrophic year where all dryland crops would fail, and the wet year is an example of timely rain events in the spring. However, too much rainfall during the fall interferes with harvest and many of these storms are accompanied by severe weather, i.e., high windspeed and hail that may damage crops. The same pattern of daily water evaporation calculated for the Pullman soil series (Figure 5) was also calculated for the Amarillo soil series (Figure 6) for both the dry and wet year. In the dry year and during the summer months (DOY 122 to DOY 244) there was $12 \mathrm{~mm}$ of rainfall with $20 \mathrm{~mm}$ of evaporation and in the wet year the summer rainfall was $386 \mathrm{~mm}$ with $394 \mathrm{~mm}$ lost to evaporation (Figure 6). 
These results can be used to illustrate the effect of surface residue, minimum tillage and self-mulching on modifying the rate of water evaporation. Indeed, surface residues retard the rate of evaporative losses and extend the total amount of time that would be required to evaporate the same amount of water, when compared to a bare surface [58] [59]. Regardless, the total amount, i.e., the integral, of water evaporated from a bare soil surface compared to surface with residue is the same and it is the rate of evaporation that differs. Further, clayey soils such as the Pullman series have an inherent characteristic that they tend to self-mulch [62]. The net result of minimum tillage [54] is to reduce soil water evaporation compared to conventional practices. The combination of surface residue and minimum tillage can in effect increase the water use efficiency of a crop, i.e., crop water use per unit water transpired, without additional input of water [52]. Our results suggest that storage of rainfall in combination with management of minimum tillage and surface residue could be achieved in the Pullman soil series in years of average or wetter rainfall. However, this would be a more difficult task to achieve in the Amarillo soil series and they would be categorized as a soil series with a higher risk for crop production.

The cumulative plots of rainfall and of evaporation of water as a function of DOY, for both soil series on the dry year (Figure 7(a)) and the wet year (Figure $7(c)$ ) show the evolution of water into or out, i.e., storage, in the soil profile. The storage of water for both soil series is shown in Figure 7(b) for the dry year and in Figure 7(d) for the wet year. In the dry year, the Amarillo soil shows a negative value throughout the year and a positive value for the Pullman soil (Figure $7(b))$. In the wet year, the differences in storage capacity for the Pullman are in sharp contrast compared to the Amarillo soil (Figure 7(d)). The storage of water in the Pullman series is positive throughout the year, gradually increasing from $+25 \mathrm{~mm}$ on DOY 30 , to about $+150 \mathrm{~mm}$ on DOY 130 , and thereafter fluctuates $\pm 25 \mathrm{~mm}$, ending with a value of $+140 \mathrm{~mm}$. The pattern in the Amarillo soil series is very different and begins with a $-25 \mathrm{~mm}$ on DOY 120 and increasing to close to $+75 \mathrm{~mm}$ on DOY 140 and thereafter decreases to $-25 \mathrm{~mm}$ on DOY 260 , ending with a value of close to $-25 \mathrm{~mm}$. These differences in storage capacity of the two-soil series are directly related to their respective soil hydraulic properties (Figure 3 and Figure 4). These simulated results illustrate that the Pullman soils are better suited to store rainfall for subsequent crop water use. However, site-specific use of crop residues and minimum tillage can be used on both soil series to maximize infiltration and to reduce runoff [57] [58] [59].

The daily evaporation and rainfall for a period of 70 days, from DOY 100 to DOY 170, for the Pullman soil in the wet year, is shown in Figure 8. The cumulative evaporation for this 70-day period was $214 \mathrm{~mm}$ with $372 \mathrm{~mm}$ of rain. Note that there were eight rain events of $>20 \mathrm{~mm}$ and of these, three events were $>40$ $\mathrm{mm}$ on DOY 134, 164 and 170. This is the type of wet period were the rainfall rate exceeds the infiltration capacity, leading to runoff. However, only $5 \mathrm{~mm}$ of runoff (Table 3) were calculated. Details regarding runoff as a function of fall rates will be subject of a separate article. 
Examples of daily water evaporation from DOY 160 to DOY 190 for the wet and dry year for the Pullman and Amarillo soil series are shown in Figure 9. In the wet year, there was a rain event of $41 \mathrm{~mm}$ on DOY 164 and of $50 \mathrm{~mm}$ on DOY 170 and the total rainfall was $152 \mathrm{~mm}$, and no rain occurred in the dry year. The daily water evaporation from the Amarillo was $\geq$ than from the Pullman on both the dry and wet year. The dry year, is an example of the perils of extreme arid conditions due to no rainfall, showing the low daily values of water evaporation. This example of a dry cycle is not unusual in the THP and under these circumstances there are no viable options to assure a successful dryland crop. In the wet year, the cumulative daily evaporation was $141 \mathrm{~mm}$ in the Amarillo and $107 \mathrm{~mm}$ in the Pullman series, and in the dry year the cumulative evaporation was $3 \mathrm{~mm}$ for the Amarillo vs. $1 \mathrm{~mm}$ in the Pullman series. The self-mulching property of the Pullman soil is evident following the pattern of evaporation on DOY 171, where the evaporation rate dropped from 9 to $2 \mathrm{~mm} / \mathrm{d}$ on DOY 180. Similarly, for the Amarillo series the daily evaporation rate decreased from 9 to $4 \mathrm{~mm} / \mathrm{d}$ over the same time period, indicating that a higher rate of evaporation was maintained resulting in less water stored in the soil. Further, in the dry year, the daily pattern of soil water evaporation for the Amarillo series shows a gradual decline, from $0.12 \mathrm{~mm} / \mathrm{d}$ to $0.08 \mathrm{~mm} / \mathrm{d}$; however, the daily pattern for the Pullman soil series fluctuates, i.e., increasing and decreasing the day after; albeit, these fluctuations are $>0.05 \mathrm{~mm} / \mathrm{d}$. These variations between the two-soil series are due to the differences in soil hydraulic properties (Figure 3 and Figure 4) of the surface layers. Further, this is an example of the self-mulching capacity of the Pullman soil due to its higher clay content on the surface horizon of $41 \%$ clay compared to $21 \%$ in the Amarillo soil series (Table 1). A difficulty in managing crops under dryland conditions and on the decision to plant a cover crop for residue management is the uncertainty of forecasting rainfall [63]. This by far is the largest impediment to assure a successful dryland crop every year.

As previously noted, the storage of rainfall in the soil is a function of many soil properties and characteristics of the rain event (intensity and duration). Of particular interest is the detention of water on the soil surface to allow more time for the water to infiltrate in the soil. This practice via the use of furrow dikes [64] has been shown to be successful to harvest rainfall across the landscape [65]. Simulation of the effects of different detention capacities on rainfalls of different rates and amount is a subject of a forthcoming article.

\section{Summary and Conclusion}

The Texas High Plains is in a state of transition from limited irrigation to an increasing amount of dryland production. This evolution is due to the fact that a saturated thickness of $9 \mathrm{~m}$, the minimum required to sustain irrigation, from the Ogallala aquifer has already been reached throughout many areas of the THP (Figure 2), particularly in regions south of Lubbock, Texas. We define dryland production as crop production without irrigation and in a semiarid climate. For 
dryland production to be a viable option in this region we need to quantify the water balance region and to understand how to minimize losses of water to evaporation and runoff and to maximize infiltration and thus storage of rainfall in the soil. As a first analysis we used the mechanistic model, ENWATBAL, to evaluate three scenarios of rainfall in this region: a dry year (189 mm of rain), an average year with ( $449 \mathrm{~mm}$ of rain) and a wet year ( $669 \mathrm{~mm}$ of rain). These three scenarios were applied to two major soil series of this region: Pullman and Amarillo. In all simulations, we used hourly input weather data for a location near Lubbock, Texas and used measured soil hydraulic properties to simulate the water balance for each soil series and the three rainfall scenarios. Results showed that storage of rainfall is possible in the Pullman soil series and is more challenging for the Amarillo series. In years with average and above average rainfall, storage of rainfall and reduction of evaporative losses from the soil surface could be enhanced and achieved by combining the use of furrow dikes with minimum tillage practices along with crop covers that provide a surface residue. The implications of our results for dryland crop production in the semiarid climate of the THP suggest that for years with average and wetter rainfall the Pullman soil series could store water in the soil that would be available for crop use. However, this was not the case for the Amarillo soil series and these soils represent a higher risk for dryland crop production.

\section{Acknowledgements}

This research was in part supported by the part by the Ogallala Aquifer Program, a consortium between USDA-Agricultural Research Service, Kansas State University, Texas A\&M AgriLife Research, Texas A\&M AgriLife Extension Service, Texas Tech University, and West Texas A\&M University.

\section{Declaration}

The US Department of Agriculture (USDA) prohibits discrimination in all its programs and activities on the basis of race, color, national origin, age, disability, and where applicable, sex, marital status, familial status, parental status, religion, sexual orientation, genetic information, political beliefs, reprisal, or because all or part of an individual's income is derived from any public assistance program. (Not all prohibited bases apply to all programs.) Persons with disabilities who require alternative means for communication of program information (Braille, large print, audiotape, etc.) should contact USDA's TARGET Center at (202) 720-2600 (voice and TDD). To file a complaint of discrimination, write to USDA. Director, Office of Civil Rights, 1400 Independence Avenue, S.W. Washington, D.C. 20250-9410, or call (800) 795-3272 (voice) or (202) 720-6382 (TDD). USDA is an equal opportunity provider and employer. Mention of trade names or commercial products in this publication is solely for the purpose of providing specific information and does not imply recommendation or endorsement by the USDA. 


\section{Conflicts of Interest}

The authors declare no conflicts of interest regarding the publication of this paper.

\section{References}

[1] Arneson, E.P. (1921) Early Irrigation in Texas. The Southwestern Historical Quarterly, 25, 121-130.

[2] Bloodworth, M.E. and Gillett, P.T. (1984) IRRIGATION. Handbook of Texas Online. Texas State Historical Association, Austin. https://tshaonline.org/handbook/online/articles/ahi01

[3] Opie, J. (2000) Ogallala: Water for a Dry Land. 2nd Edition, University of Nebraska Press, Lincoln, 477 p.

[4] Musick, J.T., Pringle, F.B. and Walker, J.J. (1988) Sprinkler and Furrow Irrigation trends: Texas High Plains. Applied Engineering in Agriculture, 4, 46-52. https://doi.org/10.13031/2013.26578

[5] Musick, J.T., Pringle, F.B., Harman, W.L. and Stewart, B.A. (1990) Long-Term Irrigation Trends: Texas High Plains. Applied Engineering in Agriculture, 6, 717-724. https://doi.org/10.13031/2013.26454

[6] Colaizzi, P.D., Gowda, P.H., Marek, T.H. and Porter, D.P. (2009) Irrigation in the Texas High Plains: A Brief History and Potential Reductions in Demand. Irrigation and Drainage, 58, 257-274. https://doi.org/10.1002/ird.418

[7] Scanlon, B.R., Faunt, C.C., Longuevergne, L., Reedy, R.C., Alley, W.M., McGuire, V.L. and McMahon, P.B. (2012) Groundwater Depletion and Sustainability of Irrigation in the US High Plains and Central Valley. Proceedings of the National Academy of Sciences, USA, 109, 9320-9325.

https://doi.org/10.1073/pnas.1200311109

[8] Lascano, R.J. (2000) A General System to Measure and Calculate Daily Crop Water Use. Agronomy Journal, 92, 821-832. https://doi.org/10.2134/agronj2000.925821x

[9] Mahan, J.R. and Lascano, R.J. (2016) Irrigation Analysis Based on Long-Term Weather Data. Agriculture, 6, 42. https://doi.org/10.3390/agriculture6030042

[10] Jackson, R.D., Idso, S.B., Reginato, R.J. and Pinter, P.J. (1981) Canopy Temperature as a Crop Water Stress Indicator. Water Resources Research, 7, 1133-1138. https://doi.org/10.1029/WR017i004p01133

[11] Jackson R.D., Kustas, W.P. and Choudhury, B.J. (1988) A Re-Examination of the Crop Water Stress Index. Irrigation Science, 9, 309-317.

https://doi.org/10.1007/BF00296705

[12] Wanjura D.F., Upchurch, D.R. and Mahan, J.R. (1995) Control of Irrigation Scheduling Using Temperature-Time Thresholds. Transactions of the American Society of Agricultural Engineers, 38, 403-409. https://doi.org/10.13031/2013.27846

[13] Mahan, J.R., Burke, J.J., Wanjura, D.F. and Upchurch, D.R. (2005) Determination of Temperature and Time Thresholds for BIOTIC Irrigation of Peanut on the Southern High Plains of Texas. Irrigation Science, 23, 145-152. https://doi.org/10.1007/s00271-005-0102-9

[14] Davis, S.L. and Dukes, M.D. (2010) Irrigation Scheduling Performance by Evapotranspiration-Based Controllers. Agricultural Water Management, 98, 19-28. https://doi.org/10.1016/j.agwat.2010.07.006

[15] Jones, H.G. (2004) Irrigation Scheduling: Advantages and Pitfalls of Plant-Based 
Methods. Journal of Experimental Botany, 55, 2427-2436. https://doi.org/10.1093/jxb/erh213

[16] Lyle, W.M. and Bordovsky, J.P. (1981) Low Energy Precision Application (LEPA) Irrigation System. Transactions of the American Society of Agricultural Engineers, 24, 1241-1245. https://doi.org/10.13031/2013.34427

[17] Lyle, W.M. and Bordovsky, J.P. (1983) LEPA Irrigation System Evaluation. Transactions of the American Society of Agricultural Engineers, 26, 776-781. https://doi.org/10.13031/2013.34022

[18] Camp, C.R. (1998) Subsurface Drip Irrigation: A Review. Transactions of the American Society of Agricultural and Biological Engineers, 41, 1353-1367. https://doi.org/10.13031/2013.17309

[19] Bordovsky, J.P. and Porter, D.O. (2008) Effect of Subsurface Drip Irrigation System Uniformity on Cotton Production in the Texas High Plains. Applied Engineering in Agriculture, 24, 465-472. https://doi.org/10.13031/2013.25147

[20] Goebel, T.S. and Lascano, R.J. (2019) Rainwater Use by Cotton under Subsurface Drip and Center Pivot Irrigation. Agricultural Water Management, 215, 1-7. https://doi.org/10.13031/2013.25147

[21] McGuire, V.L. (2001) Water-Level Changes in the High Plains Aquifer, 1980 to 1999. U.S. Geological Service. Publication USGS FS-029-01, 2 p. https://doi.org/10.3133/fs02901

[22] (2019) High Plains Underground Water Conservation District No. 1. Annual Report, $31 \mathrm{p}$. https://static1.squarespace.com/static/53286fe5e4b0bbf6a4535d75/t/5e1f211bc7e17a lfcb0bbabe/1579098401287/2019+Annual+Report+\%28Final\%29.pdf

[23] Grafton, R.Q., Williams, J., Perry, C.J., Molle, F., Ringler, C., Steduto, P., Udall, B., Wheeler, S.A., Wang, Y., Garrick, D. and Allen, R.G. (2018) The Paradox of Irrigation Efficiency. Science, 361, 748-750. https://doi.org/10.1126/science.aat9314

[24] Stewart, B.A., Koohafkan, P. and Ramamoorthy, K. (2006) Dryland Agriculture Defined and Its Importance to the World. In: Peterson, G.A., Unger, P.W. and Payne, W.A., Eds., Dryland Production, 2nd Edition, Agronomy Monograph No. 23, American Society of Agronomy, Crop Science Society of America, Soil Science Society of America, Madison, 1-26. https://doi.org/10.2134/agronmonogr23.2ed.c1

[25] Hegde, B.R. (1995) Dryland Farming: Past Progress and Future Prospects. In: Singh, R.P., Ed., Sustainable Development of Dryland Agriculture in India, Scientific Publication, Jodhpur, 7-12.

[26] Hargreaves, M.W.M. (1957) Dry Farming in the Northern Great Plains: 1900-1925. Harvard University Press, Cambridge.

[27] Stewart, B.A. and Burnett, E. (1987) Water Conservation Technology in Rainfed and Dryland Agriculture. Proceedings of the Conference, College Station, 26-30 May 1985, 355-359.

[28] Mathews, O.R. and Cole, J.S. (1938) Special Dry-Farming Problems. In: Soils and Men, Yearbook of Agriculture, USDA, Washington DC, 679-692.

[29] Peel, M.C., Finlayson, B.L. and McMahon, T.A. (2007) Updated World Map of the Köppen-Geiger Climate Classification. Hydrology and Earth System Sciences, 11, 1633-1644. https://doi.org/10.5194/hess-11-1633-2007

[30] Unger, P.W. and Pringle, F.B. (1981) Pullman Soils: Distribution, Importance, Variability, and Management. Bulletin, B-1372. Texas Agricultural Experiment Station, College Station. 
[31] Unger, P.W. and Pringle, F.B. (1998) Olton Soils: Distribution, Importance, Variability, and Management. Bulletin, B-1727. Texas Agricultural Experiment Station, College Station.

[32] Baumhardt, R.L., Lascano, R.J. and Krieg, D.R. (1995) Physical and Hydraulic Properties of a Pullman and Amarillo Soil on the Texas High Plains. Texas A\&M University Agricultural Research and Extension Center at Lubbock/Halfway, Technical Report No. 95-1, 20 p.

[33] Isom, W.H. and Worker, G.F. (1979) Crop Management in Semi-Arid Environments. In: Hall, A.E., Cannell, G.H. and Lawton, H.W., Eds., Agriculture in Semi-Arid Environments, Ecological Studies 34, Springer-Verlag, Berlin, Heidelberg, New York 200-223. https://doi.org/10.1007/978-3-642-67328-3 8

[34] Boers, Th.M. and Ben-Asher, J. (1982) A Review of Rainwater Harvesting. Agricultural Water Management, 5, 145-158. https://doi.org/10.1016/0378-3774(82)90003-8

[35] Turner, N.C. (2004) Agronomic Options for Improving Rainfall-Use Efficiency of Crops in Dryland Farming Systems. Journal of Experimental Botany, 55, 2412-2425. https://doi.org/10.1093/jxb/erh154

[36] Lascano, R.J. and van Bavel, C.H.M. (1983) Experimental Verification of a Model to Predict Soil Moisture and Temperature Profiles. Soil Science Society of America Journal, 47, 441-448. https://doi.org/10.2136/sssaj1983.03615995004700030010x

[37] Lascano, R.J. and van Bavel, C.H.M. (1986) Simulation and Measurement of Evaporation from a Bare Soil. Soil Science Society of America Journal, 50, 1127-1132. https://doi.org/10.2136/sssaj1986.03615995005000050007x

[38] Evett, S.R. and Lascano, R.J. (1993) ENWATBAL.BAS: A Mechanistic Evapotranspiration Model Written in Compiled BASIC. Agronomy Journal, 85, 763-772. https://doi.org/10.2134/agronj1993.00021962008500030044x

[39] Jones, J.W., Hoogenboom, G., Porter, C.H., Boote, K.J., Batchelor, W.D., Hunt, L.A., Wilkens, P.W., Singh, U., Gijsman, A.J. and Richie, J.T. (2003) The DSSAT Cropping System Model. European Journal of Agronomy, 18, 235-265. https://doi.org/10.1016/S1161-0301(02)00107-7

[40] Hunt, J.C.R. (1998) Lewis Fry Richardson and His Contributions to Mathematics, Meteorology, and Models of Conflict. Annual Review of Fluid Mechanics, 30, 13-36. https://doi.org/10.1146/annurev.fluid.30.1.0v

[41] Szeicz, G., van Bavel, C.H.M. and Takami, S. (1973) Stomatal Factor in the Water Use and Dry Matter Production of Sorghum. Agricultural Meteorology, 12, 361-389. https://doi.org/10.1016/0002-1571(73)90032-0

[42] Van Bavel, C.H.M. and Hillel, D.I. (1976) Calculating Potential and Actual Evaporation from a Bare Soil Surface by Simulation of Concurrent Flow of Water and Heat. Agricultural Meteorology, 17, 453-476.

https://doi.org/10.1016/0002-1571(76)90022-4

[43] Galperin, B., Sukoriansky, S. and Anderson, P.S. (2007) On the Critical Richardson Number in Stably Stratified Turbulence. Atmospheric Science Letters, 8, 65-69. https://doi.org/10.1002/asl.153

[44] Dane, J.H. and Hopmans, J.W. (2002) Water Retention and Storage. In: Dane, J.H. and Topp, G.C., Eds., Methods of Soil Analysis. Part 4, Physical Methods, Soil Science Society of America, Madison, 671-720.

[45] Jackson, R.D. (1972) On the Calculation of Hydraulic Conductivity. Soil Science Society America Proceedings, 36, 380-382. https://doi.org/10.2136/sssaj1972.03615995003600020047x 
[46] Van Genuchten, M.Th. (1980) A Closed-Form Equation for Predicting the Hydraulic Conductivity of Unsaturated Soils. Soil Science Society of America Journal, 44, 892-898. https://doi.org/10.2136/sssaj1980.03615995004400050002x

[47] De Vries, D.A. (1966) Thermal Properties of Soils. In: van Wijk, W.R., Eds., Physics of Plant Environment, Chapter No. 7, North Holland Publishing Company, Amsterdam, 210-235.

[48] Schroder, J.L., Burgett, W.S., Haynie, K.B., Sonmez, I., Skwira, G.D., Doggett, A.L., and Lipe, J.W. (2005) The West Texas Mesonet: A Technical Overview. Journal of Atmospheric and Oceanic Technology, 22, 211-222. https://doi.org/10.1175/JTECH-1690.1

[49] Krieg, D.R. and Lascano, R.J. (1990) Sorghum. In: Stewart, B.A. and Nielsen, D.R., Eds., Irrigation of Agricultural Crops, Agronomy Monograph No. 30, American Society of Agronomy, Crop Science Society of America, Soil Science Society of America, Madison, 719-739.

[50] Lascano, R.J. and Baumhardt, R.L. (1996) Effects of Crop Residue on Soil and Plant Water Evaporation in a Dryland Cotton System. Theoretical Applied Climatology, 54, 69-84. https://doi.org/10.1007/BF00863560

[51] Lascano, R.J., van Bavel, C.H.M., Hatfield, J.L. and Upchurch, D.R. (1987) Energy and Water Balance of a Sparse Crop: Simulated and Measured Soil and Crop Evaporation. Soil Science Society of America Journal, 51, 1113-1121. https://doi.org/10.2136/sssaj1987.03615995005100050004x

[52] Lascano, R.J., Baumhardt, R.L., Hicks, S.K. and Heilman, J.L. (1994) Soil and Plant Water Evaporation from Strip-Tilled Cotton: Measurement and Simulation. Agronomy Journal, 86, 987-994. https://doi.org/10.2134/agronj1994.00021962008600060011x

[53] Qiu, G.Y., Momii, K., Yano, T. and Lascano, R.J. (1999) Experimental Verification of a Mechanistic Model to Partition Evapotranspiration into Soil Water and Plant Evaporation. Agricultural and Forest Meteorology, 93, 79-93. https://doi.org/10.1016/S0168-1923(98)00115-4

[54] Unger, P.W. and McCalla, T.M. (1980) Conservation Tillage Systems. Advances in Agronomy, 33, 1-58. https://doi.org/10.1016/S0065-2113(08)60163-7

[55] Keeling, W., Segarra, E. and Abernathy, J.R. (1989) Evaluation of Conservation Tillage Cropping Systems for Cotton on the Texas Southern High Plains. Journal of Production Agriculture, 2, 269-273. https://doi.org/10.2134/jpa1989.0269

[56] Buman, R.A., Alesii, B.A., Bradley, J.F., Hatfield, J.L. and Karlen, D.L. (2005) Profit and Yield of Tillage in Cotton Production Systems. Journal of Soil and Water Conservation, 60, 235-242.

[57] Baumhardt, R.L. and Lascano, R.J. (1996) Rain Infiltration as Affected by Wheat Residue Amount and Distribution in Ridged Tillage. Soil Science Society of America Journal, 60, 1908-1913. https://doi.org/10.2136/sssaj1996.03615995006000060041x

[58] Baumhardt, R.L. and Lascano, R.J. (1999) Water Budget and Yield of Dryland Cotton Intercropped with Terminated Winter Wheat. Agronomy Journal, 91, 922-927. https://doi.org/10.2134/agronj1999.916922x

[59] Lascano, R.J., Krieg, D.R., Baker, J.T., Goebel, T.S. and Gitz III, D.C. (2015) Planting Cotton in a Crop Residue in a Semiarid Climate: Water Balance and Lint Yield. Open Journal of Soil Science, 5, 236-249. https://doi.org/10.4236/ojss.2015.510023

[60] Kibblewhite, M.G., Ritz, K. and Swift, M.J. (2008) Soil Health in Agricultural Systems. Philosophical Transactions of the Royal Society B, 363, 685-701. 
https://doi.org/10.1098/rstb.2007.2178

[61] Turmel, M.S., Speratti, A., Baudron, F., Verhulst, N. and Govaerts, B. (2015) Crop Residue Management and Soil Health: A System Analysis. Agricultural Systems, 134, 6-16. https://doi.org/10.1016/j.agsy.2014.05.009

[62] Grant, C.D. and Blackmore, A.V. (1991) Self-Mulching Behavior in Clay Soils: Its Definition and Measurement. Australian Journal of Soil Research, 26, 155-173. https://doi.org/10.1071/SR9910155

[63] Baumhardt, R.L., Mauget, S.A., Schwartz, R.C. and Jones, O.R. (2016) El Niño Southern Oscillation Effects on Dryland Crop Production in the Texas High Plains. Agronomy Journal, 108, 736-744. https://doi.org/10.2134/agronj2015.0403

[64] Jones, O.R. and Clark, R.N. (1987) Effects of Furrow Dikes on Water Conservation and Dryland Crop Yields. Soil Science Society of America Journal, 51, 1307-1314. https://doi.org/10.2136/sssaj1987.03615995005100050039x

[65] Lascano, R.J. and Nelson, J.R. (2015) Circular Planting to Enhance Rainfall Capture in Dryland Cropping Systems at a Landscape Scale: Measurement and Simulation. In: Ahuja, L.R., Ma, L.W. and Lascano, R.J., Eds., Advances in Agricultural Systems Modeling, Volume 5, American Society of Agronomy, Crop Science Society of America, Soil Science Society of America, Madison, 85-111.

https://doi.org/10.2134/advagricsystmodel5.c4 